\title{
Cytomegalovirus infection in gastrointestinal tracts of patients infected with HIV-1 or AIDS
}

\author{
N D FRANCIS, A W BOYLSTON, A H G ROBERTS, J M PARKIN, * A J PINCHING* \\ From the Departments of Histopathology and *Immunology, St Mary's Hospital, London
}

SUMMARY All gastrointestinal tract biopsy specimens from 190 patients positive for HIV-1 or with AIDS were reviewed to assess the prevalence of cytomegalovirus (CMV) infection, morphology of infected cells, and the associated histopathological features. Eighteen patients $(10(7 \cdot 7 \%)$ of $129 \mathrm{HIV}$ antibody positive and eight (13.1\%) of 61 with AIDS) had CMV identified in 35 biopsy specimens from the following sites: oesophagus $(n=3)$; stomach $(n=6)$; small intestine $(n=4)$; colorectum $(n=18)$ and perianal area $(n=4)$. Eleven patients had CMV alone as the potential cause of symptoms and in seven there were coexistent pathogens or Kaposi's sarcoma. The appearance and type of infected cells at different sites was highly variable. Immunocytochemical techniques and electron microscopic examination were performed to confirm the presence of CMV antigen and CMV virus particles and to exclude the possibility of an adenovirus producing similar cytopathic changes.

It is important to recognise the different morphological forms of infected cells, and the use of immunocytochemical techniques is recommended in patients at risk for CMV or in whom CMV infection is suspected.

Cytomegalovirus (CMV) is a common infectious agent in patients infected with HIV-1, in whom it may cause retinitis, pnemonitis, cerebral infection and gastrointestinal disease. ${ }^{1-3} \mathrm{CMV}$ may be found in the gastrointestinal tract of symptomless patients, ${ }^{4}$ or it may be associated with a wide variety of inflammatory processes. ${ }^{56}$ It has been estimated that the prevalence of serious gastrointestinal CMV disease complicating AIDS is $2 \cdot 2 \%{ }^{1}$ and that gastrointestinal tract disturbance is the second commonest manifestation, after retinitis, of severe CMV infection. It is generally accepted that when CMV inclusion cells are seen they indicate active virus production and that they are usually associated with pathological lesions. ${ }^{78}$ The diagnosis of CMV as the potential cause of lesions depends on the identification of infected cells or culture of the virus from that site; until recently the former has relied on morphology alone.

This study was performed to assess the importance of CMV in a consecutive series of 190 patients seropositive for HIV-1 with gastrointestinal symptoms which required endoscopic investigation and biopsy. It was also performed to describe in detail the appearances and location of infected cells, to increase awareness of atypical cells, and so improve diagnostic

Accepted for publication 25 May 1989 sensitivity, and to establish whether any of the cases had pathological effects attributable to adenovirus, which was isolated from stool specimens in a small number.

\section{Patients and methods}

The biopsy specimens of all HIV-1 antibody positive patients who had gastrointestinal biopsy performed between 1982 and 1988 were reviewed for the presence of cells showing features of CMV infection. Patients with a diagnosis of AIDS according to the Centers for Disease Control revised criteria, ${ }^{9}$ in whom HIV testing had not been performed, were also reviewed. Cases with evidence of CMV were studied in detail and form the basis of this report. CMV infection was diagnosed by finding CMV inclusion cells. These were either of the classic Cowdry A type or of the types described below. The "gold standard" for diagnosis was the finding of these cells or positive staining by immunocytochemical techniques.

Immunocytochemical techniques were performed on all cases for which additional material was available. Paraffin wax sections were dewaxed and treated with trypsin for 12 minutes. The primary antibody was a mouse monoclonal (Dako M757) used at a dilution of $1 / 30$ and incubated for two hours at room temperature in a humidified chamber. After washing, 
Table 1 Clinical and biopsy details of cases positive for CMV

\begin{tabular}{|c|c|c|c|c|c|c|}
\hline \multirow[b]{2}{*}{ Case No } & \multirow[b]{2}{*}{ Clinical presentation } & \multicolumn{5}{|c|}{ Biopsy site (No positive/total No of biopsies) } \\
\hline & & $O$ & $\boldsymbol{S}$ & $\boldsymbol{S I}$ & $\boldsymbol{C R}$ & $A$ \\
\hline $\begin{array}{l}1 \\
2 \\
3 \\
4 \\
5 \\
6 \\
7 \\
8 \\
9 \\
10 \\
11 \\
12 \\
13 \\
14 \\
15 \\
16 \\
17 \\
18\end{array}$ & $\begin{array}{l}\text { HIV dysphagia and malabsorption } \\
\text { HIV dysphagia, ulcerated oesophagus } \\
\text { AIDS, diarrhoea and vomiting, oesophageal ulcer } \\
\text { AIDS ? Kaposi's sarcoma } \\
\text { AIDS, dyspepsia, Kaposi's sarcoma at endoscopy } \\
\text { AIDS } 3 / 12 \text { abdominal pain with diarrhoea } \\
\text { HIV } 2 / 12 \text { watery diarrhoea, ? ulcerative colitis } \\
\text { AIDS } 1 / 52 \text { diarrhoea and colitis } \\
\text { HIV/ARC } 1 / 52 \text { dysphagia, diarrhoea } \\
\text { HIV } 4 / 12 \text { diarrhoea } \\
\text { HIV } 6 / 12 \text { diarrhoea/blood, ulcer } 10 \mathrm{~cm} \\
\text { HIV } 1 / 12 \text { colitic symptoms } \\
\text { AIDS, diarrhoea, abdominal pain, fever } \\
\text { HIV } 2 / 12 \text { diarrhoea and colitis } \\
\text { AIDS } 12 / 12 \text { bowel symptoms, colitis } \\
\text { AIDS? perianal herpes } \\
\text { HIV chronic anal fissure } \\
\text { HIV chronic fissure and anal warts }\end{array}$ & $\begin{array}{l}1 / 1 \\
1 / 1 \\
1 / 2 \\
0 / 1\end{array}$ & $\begin{array}{l}1 / 1 \\
1 / 1 \\
1 / 1 \\
1 / 1 \\
\\
2 / 2\end{array}$ & $\begin{array}{l}1 / 1 \\
1 / 1 \\
1 / 1 \\
1 / 1 \\
0 / 2 \\
0 / 1\end{array}$ & $\begin{array}{c} \\
3 / 4 \\
5 / 8 \\
1 / 1 \\
1 / 1 \\
1 / 1 \\
2 / 2 \\
1 / 2 \\
1 / 1 \\
1 / 1 \\
1 / 5 \\
0 / 3 \\
0 / 2 \\
18 / 34\end{array}$ & $\begin{array}{l}1 / 1 \\
1 / 1 \\
2 / 2 \\
4 / 4\end{array}$ \\
\hline
\end{tabular}

$\mathbf{O}=$ oesophagus, $\mathbf{S}=$ stomach, $\mathrm{SI}=$ small intestine, $\mathrm{CR}=$ colorectal, $\mathbf{A}=$ anal, $\mathbf{A R C}=$ aids related complex.

biotinylated rabbit anti-mouse was applied for 30 minutes at a dilution of $1 / 500$. Avidin-biotin complex $(1 \mu \mathrm{ml}$ each in $125 \mu \mathrm{ml})$ was applied for 30 minutes, then washed, and developed with diaminobenzidine. Biopsy specimens from HIV antibody positive patients without evidence of CMV and histologically normal biopsy specimens from HIV antibody negative cases were used as controls.

Electron microscopy was performed in selected cases where adenovirus had been isolated from stool samples. Paraffin wax sections were lifted using a method described previously. ${ }^{10}$ Viral particles were then measured using a sizing grid and compared with known cases of adenovirus and CMV infection using a Phillips EM 300 transmission electron microscope.

\section{Results}

One hundred and ninety patients underwent a total of 361 gastrointestinal biopsies: oesophageal $(n=18)$, gastric $(n=53)$, small intestinal $(n=69)$, colorectal $(n=208)$ and anal $(n=13)$. Eighteen $(9 \cdot 6 \%)$ of the patients had CMV cells in 35 biopsy specimens: oesophagus $(n=3)$, stomach $(n=6)$, small intestine $(n=4)$, colorectal $(n=18)$ and anus $(n=4)$. An additional 21 biopsy specimens from nine of these 18 cases were negative for CMV: oesophagus $(n=2)$, small intestine $(n=3)$ and colorectal $(n=16)$. Clinical presentation, duration of symptoms, and clinical stage of HIV infection are shown in table 1 . Of the 190 patients, 61 were diagnosed as having AIDS before their first biopsy and 129 were HIV antibody positive but negative for AIDS. CMV infection is therefore more common in AIDS-eight of 61
$(13 \cdot 1 \%)$ than in HIV infection alone-10 of 129 $(7 \cdot 7 \%)$.

Location and semiquantitative analysis of the number of CMV infected cells, together with associated histological features and other infections of tumours are given in table 2. Table 1 shows that 10 o the patients were diagnosed as having AIDS as a resulb of the biopsy findings. Table 2 shows that in six patients there was another concomitant infectious agent or Kaposi's sarcoma - cryptosporidiosis in four and Kaposi's sarcoma in four. In two of these, cryptosporidia and Kaposi's sarcoma were present and in one case with cryptosporidia, Campylobacterlike organisms were present in the stomach with associated active chronic gastritis. Spirochaetes were found on the colonic surface epithelium in two cases but they are of uncertain pathogenic importance." Perianal herpes simplex virus could explain the symptoms of proctitis in one additional patient.

In total, 11 of the patients had CMV infection of the gastrointestinal tract as the only identifiable potential cause of their symptoms.

LOCATION AND APPEARANCE OF CMV CELLS

Infected cells were never found in the epithelium of the oesophagus but were found in endothelial cells, pericytes, and inflammatory cells (probably macrophages) in and adjacent to the areas of ulceration. Ulceration and pronounced inflammatory changes were the usual finding in the oesophagus. Immunocytochemistry was particularly helpful in differentiating CMV infected cells from other cells, especially swollen endothelial cells, in inflammatory slough. 
Table 2 Location of CMV cells and histological features

\begin{tabular}{|c|c|c|c|c|c|c|c|c|c|c|c|}
\hline \multirow{2}{*}{$\begin{array}{l}\text { Case } \\
\text { No }\end{array}$} & \multirow{2}{*}{$\begin{array}{l}\text { Biopsy } \\
\text { site }\end{array}$} & \multicolumn{7}{|c|}{ Location of CMV cells } & \multirow{2}{*}{$\begin{array}{l}\text { Electron } \\
\text { microscopy }\end{array}$} & \multirow{2}{*}{ Virology } & \multirow{2}{*}{$\begin{array}{l}\text { Histological and } \\
\text { other findings }\end{array}$} \\
\hline & & $E P I$ & $E N D$ & PERI & $L P / M$ & MUS & TOT & $I P X$ & & & \\
\hline 1 & $\begin{array}{l}\text { Oesophagus } \\
\text { Small intestine }\end{array}$ & $\overline{\text { No Cl }}$ & $\stackrel{+}{\mathrm{TV}}$ cells & + & + & - & +++ & + & ND & $\begin{array}{l}\text { CMV } \\
\text { (lung) }\end{array}$ & $\begin{array}{l}\text { Ulceration, acute and chronic } \\
\text { inflammation }\end{array}$ \\
\hline \multirow[t]{3}{*}{2} & Oesophagus & - & + & + & + & - & +++ & + & ND & - & $\begin{array}{l}\text { Ulceration, acute and chronic } \\
\text { inflammation }\end{array}$ \\
\hline & Stomach & + & - & - & + & - & $++t$ & + & ND & - & Chronic inflammation \\
\hline & Small intestine & + & - & - & + & - & ++ & + & ND & - & Mild chronic inflammation \\
\hline \multirow[t]{3}{*}{3} & Oesophagus (1) & - & + & - & + & - & ++ & + & ND & CMV & Ulcer $\mathrm{a} / \mathrm{c}$ inflammation \\
\hline & Stomach & + & + & - & + & - & $++t$ & + & ND & (lung) & $\begin{array}{l}\text { Chronic inflammation, Kaposi's } \\
\text { sarcoma }\end{array}$ \\
\hline & Colorectum (1) & - & - & + & + & + & + & ND & ND & & $\begin{array}{l}\text { a/c inflammation, glands } \\
\text { dilated, crypt abscess } \\
\text { Cryptosporidia }\end{array}$ \\
\hline \multirow[t]{2}{*}{4} & Stomach & - & + & + & + & - & +++ & + & ND & - & Chronic inflammation with few \\
\hline & Small intestine & + & + & + & + & - & +++ & + & ND & & $\begin{array}{l}\text { disrupted gastric glands. } \\
\text { Kaposi's sarcoma both sites }\end{array}$ \\
\hline 5 & Oesophagus & \multicolumn{2}{|c|}{ No CMV cells } & & & & & & & CMV & Mild chronic inflammation \\
\hline \multirow[t]{2}{*}{6} & $\begin{array}{l}\text { Stomach } \\
\text { Small intestine }\end{array}$ & $\begin{array}{l}+ \\
-\end{array}$ & $\overline{+}$ & $\overline{+}$ & $\overline{+}$ & - & $\begin{array}{l}++ \\
++\end{array}$ & $\begin{array}{l}+ \\
+\end{array}$ & $\stackrel{+}{\mathbf{N D}}$ & (lung) & $\begin{array}{l}\text { adjacent to Kaposi's sarcoma } \\
\text { Cryptosporidia + Kaposi's } \\
\text { sarcoma }\end{array}$ \\
\hline & Colorectum (3) & - & + & + & + & - & ++ & + & ND & - & $\begin{array}{l}\text { Cryptosporidia, severe oedema } \\
\text { of small intestine, a/c } \\
\text { inflammation in all areas with } \\
\text { crypt abscess }\end{array}$ \\
\hline 7 & Colorectum (5) & $+(1)$ & + & + & + & + & $++t$ & + & + & $\begin{array}{l}\text { Adenovirus } \\
\text { (st) }\end{array}$ & $\begin{array}{l}\text { Mild oedema, chronic } \\
\text { inflammation, superficial } \\
\text { ulcer in one with epithelial } \\
\text { inclusion }\end{array}$ \\
\hline 8 & Colorectum & - & + & + & + & + & ++ & + & + & - & $\begin{array}{l}\text { Mild a/c inflammation into } \\
\text { submucosa, small thrombus } \\
\text { in laminia propria vessel }\end{array}$ \\
\hline \multirow[t]{2}{*}{9} & $\begin{array}{l}\text { Stomach (2) } \\
\text { Small intestine }\end{array}$ & $\stackrel{+}{\text { No } C l}$ & IV cells & - & + & - & ++ & + & ND & $\begin{array}{l}\text { Adenovirus } \\
\text { (st) }\end{array}$ & $\begin{array}{l}\text { a/c gastritis, CLO } \\
\text { a/c inflammation into } \\
\text { subepithelial mucosa with }\end{array}$ \\
\hline & Colorectum & - & + & + & - & - & ++ & + & + & & $\begin{array}{l}\text { eosinophils. } \\
\text { Cryptosporidia + SP }\end{array}$ \\
\hline 10 & Colorectum & + & - & - & + & + & ++ & ND & ND & - & $\begin{array}{l}\text { Mild a/c inflammation into } \\
\text { muscularis mucosa }\end{array}$ \\
\hline 11 & Colorectum (2) & - & - & - & + & + & ++ & + & ND & - & $\begin{array}{l}\text { a/c inflammation with } \\
\text { eosinophils into muscularis } \\
\text { mucosa }+\mathrm{SP}\end{array}$ \\
\hline \multirow[t]{2}{*}{12} & Small intestine & \multicolumn{2}{|c|}{ No CMV cells } & & & & & & & & a/c inflammation \\
\hline & Colorectum (1) & - & - & - & - & + & + & + & ND & - & Crypt abscess \\
\hline 13 & Colorectum & - & + & + & + & + & +++ & + & ND & - & $\begin{array}{l}\text { a/c inflammation with } \\
\text { eosinophils into submucosa }\end{array}$ \\
\hline 14 & Colorectum & - & + & - & - & - & + & + & ND & - & $\begin{array}{l}\text { Chronic inflammation with few } \\
\text { dilated glands }\end{array}$ \\
\hline 15 & Colorectum (1) & - & + & - & + & - & $+t$ & + & ND & - & $\begin{array}{l}\text { Oedema, mild chronic } \\
\text { inflammation }\end{array}$ \\
\hline \multirow[t]{2}{*}{16} & Colorectum & \multicolumn{2}{|c|}{ No CMV cells } & & & & & & & & $\begin{array}{l}\text { Thrombosed vessel in } \\
\text { subepithelium inflammation }\end{array}$ \\
\hline & Anus & - & + & + & + & + & ++ & ND & $\mathbf{N D}$ & - & $\begin{array}{l}\text { Chronic inflammation of } \\
\text { subepithelial area, epithelial } \\
\text { ulcer with HSV giant cells }\end{array}$ \\
\hline 17 & Anus & + & + & + & + & - & ++ & ND & $\mathbf{N D}$ & - & $\begin{array}{l}\text { Epithelial ulcer with a/c } \\
\text { inflammation }\end{array}$ \\
\hline \multirow[t]{2}{*}{18} & Colorectum & \multicolumn{3}{|c|}{ No CMV cells } & & & & & & & $\begin{array}{l}\text { Subepithelial a/c inflammation. } \\
\text { Epithelial ulcer with } \\
\text { granulation tissue }\end{array}$ \\
\hline & Anus (2) & - & + & - & - & - & + & ND & ND & - & \\
\hline
\end{tabular}

In TOT column $+\quad=$ scanty, $<5$ cells/biopsy

$++\quad=$ moderate, $>5$ cells/biopsy

$+++=$ numerous, $>10$ cells/biopsy

In the other columns $+=$ presence but not quantity.

Numbers in parentheses indicate number of positive biopsy specimens.

Histological description refers to positive biopsies only.

Abbreviations used:

EPI = epithelial cells; $E N D=$ endothelial cells; $P E R I=$ pericytes; $L P / M=$ lamina propria cells/macrophages; TOT = semiquantitative number of CMV cells; IPX = immunoperoxidase; $M U S=$ muscle cells; $a / c=$ acute and chronic; $s t=$ stool sample; $S P=$ spirochaetosis;

CLO = Campylobacter-like organisms; HSV = herpes simplex. 


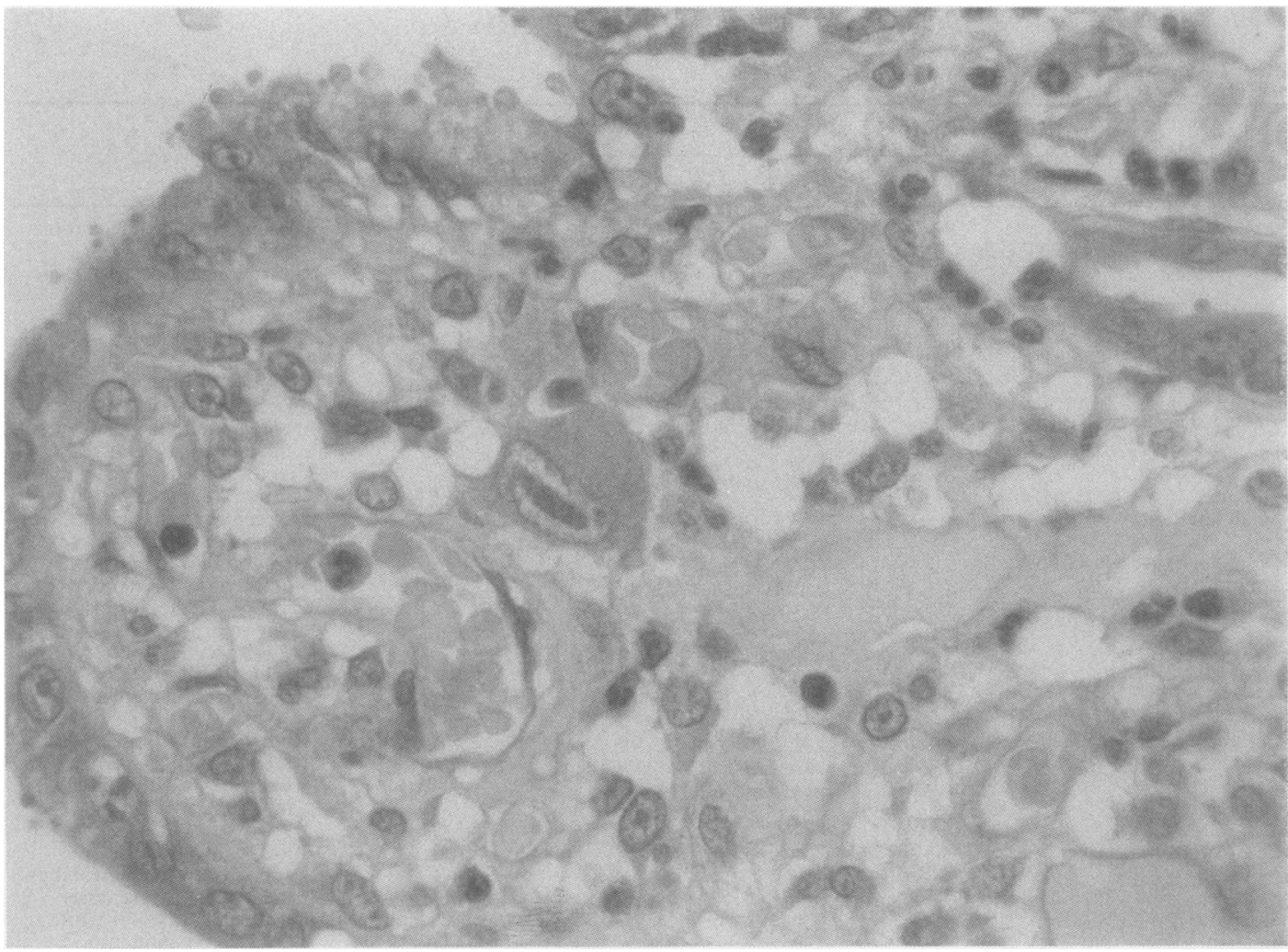

Fig 1 Typical CMV cell in lamina propria of small bowel. Cryptosporidia are also present on the surface.

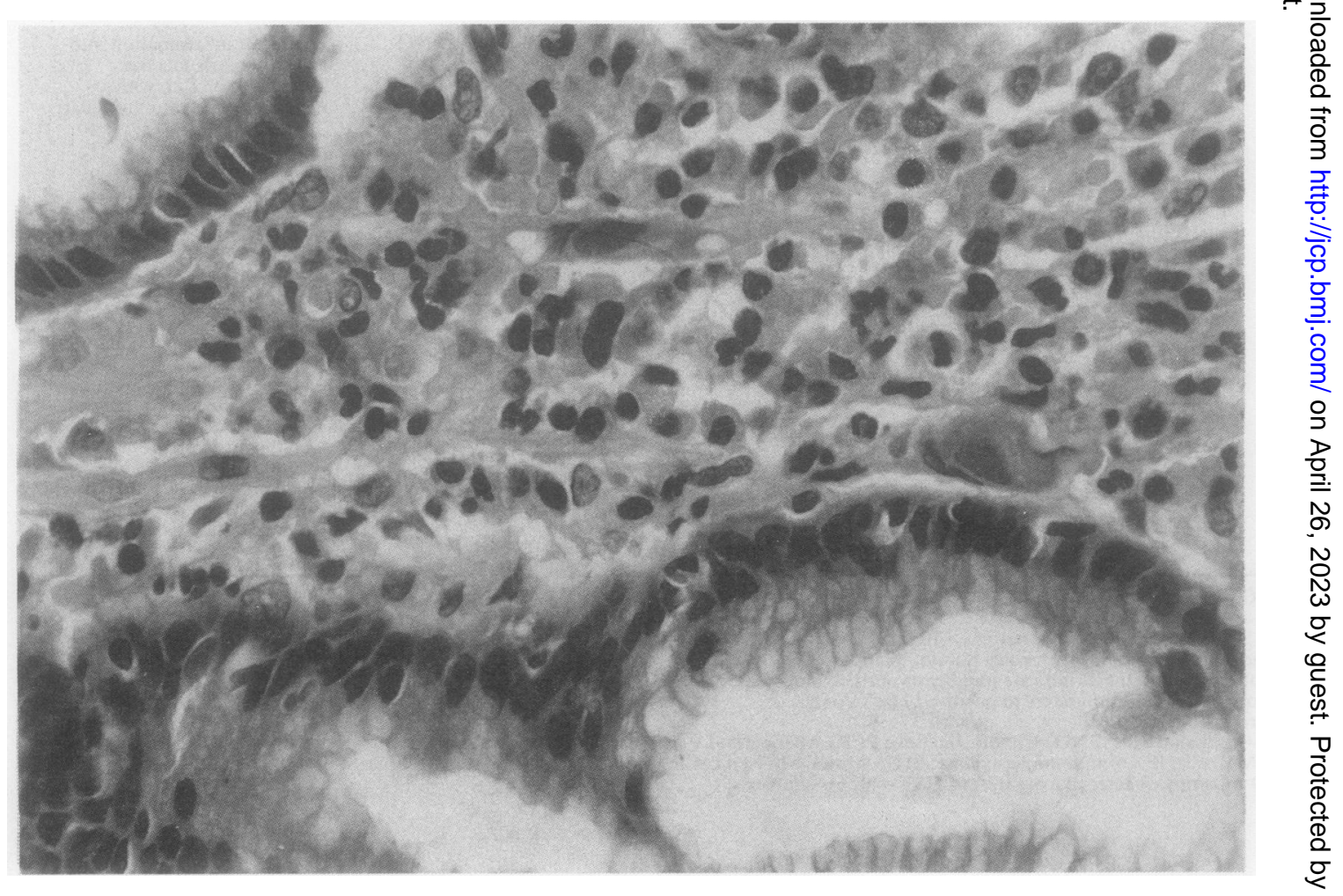

Fig 2 Atypical CMV cells in the lamina propria. 


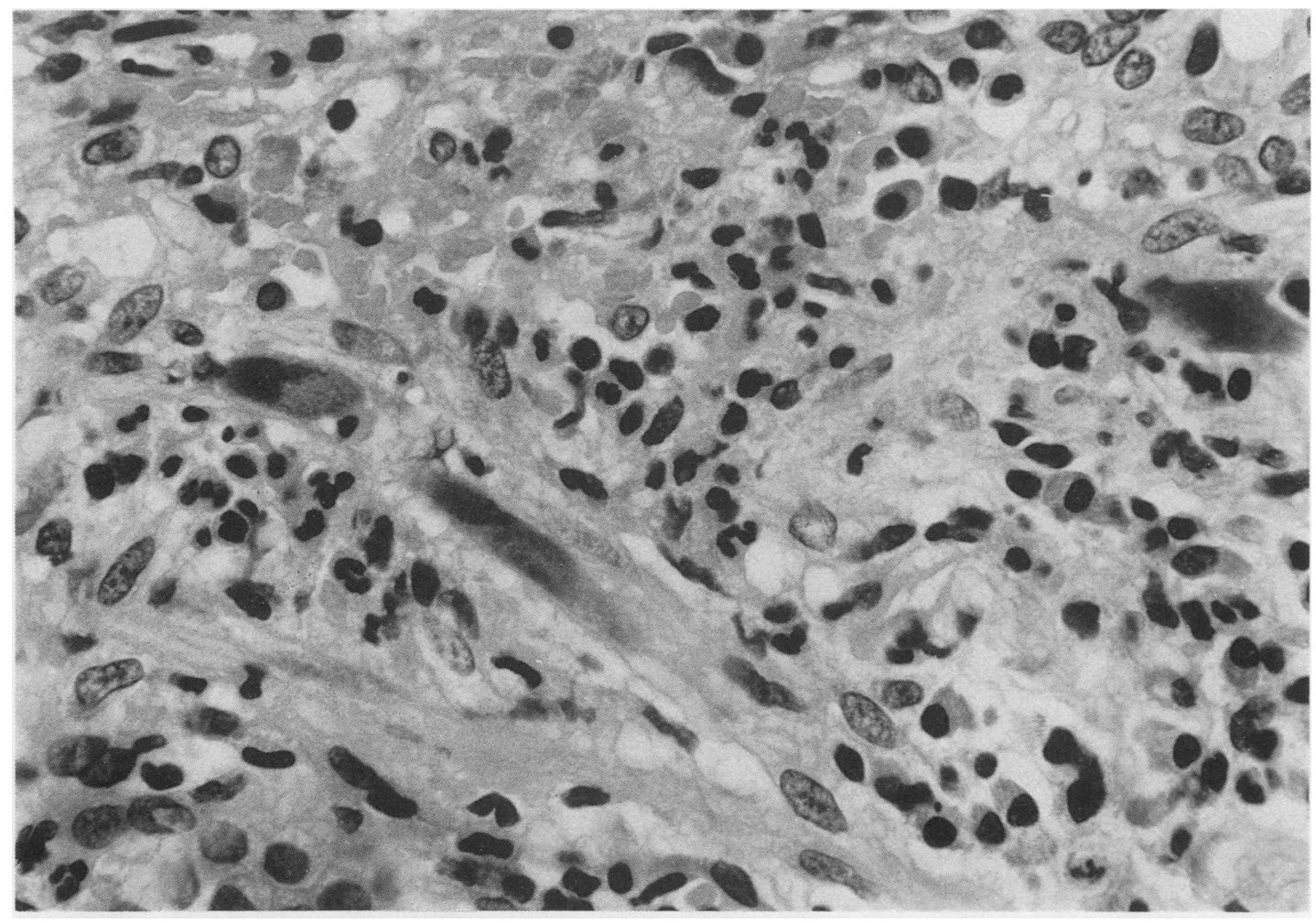

Fig 3 Elongated smudged nuclei with tapering but prominent cytoplasm.

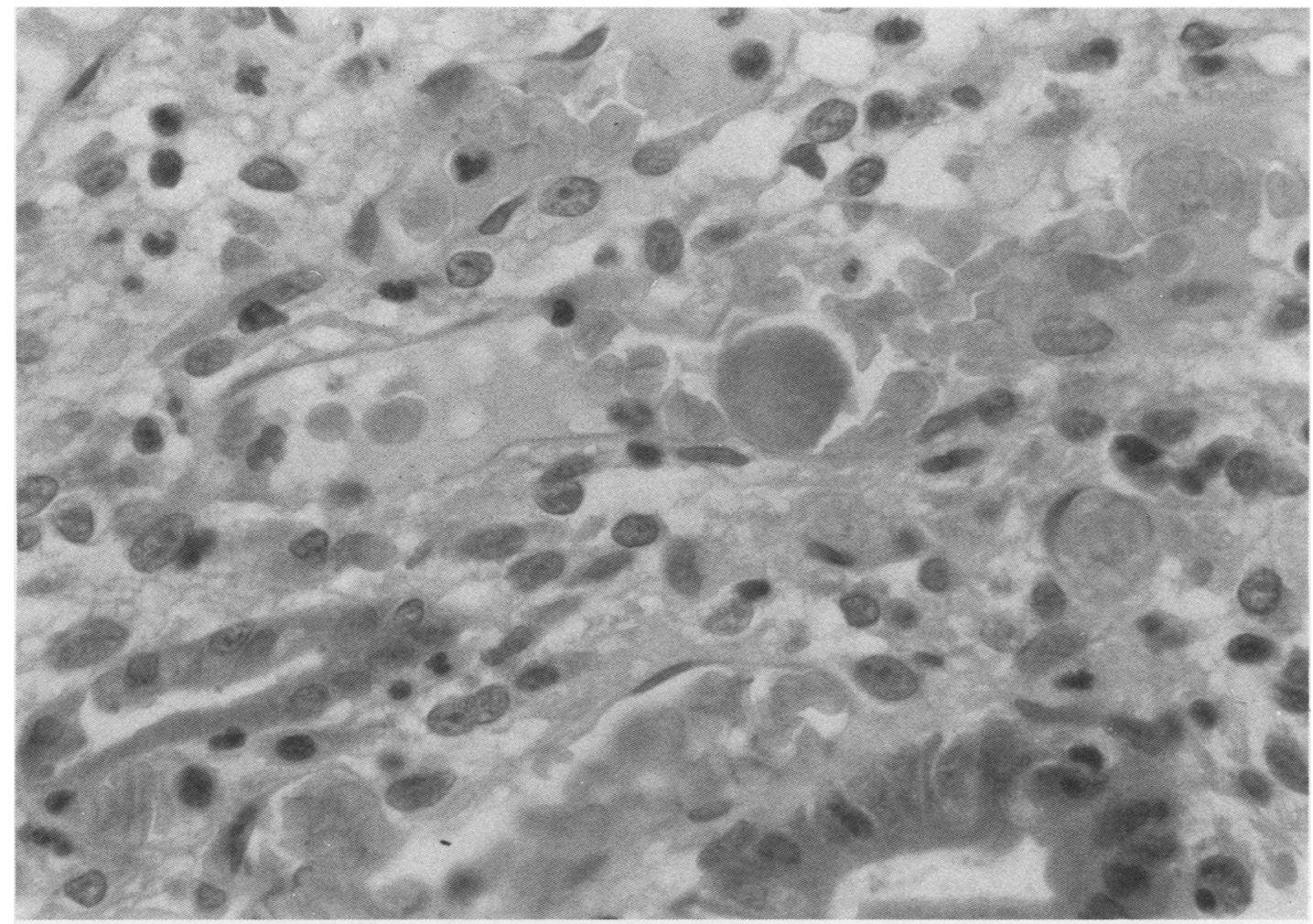




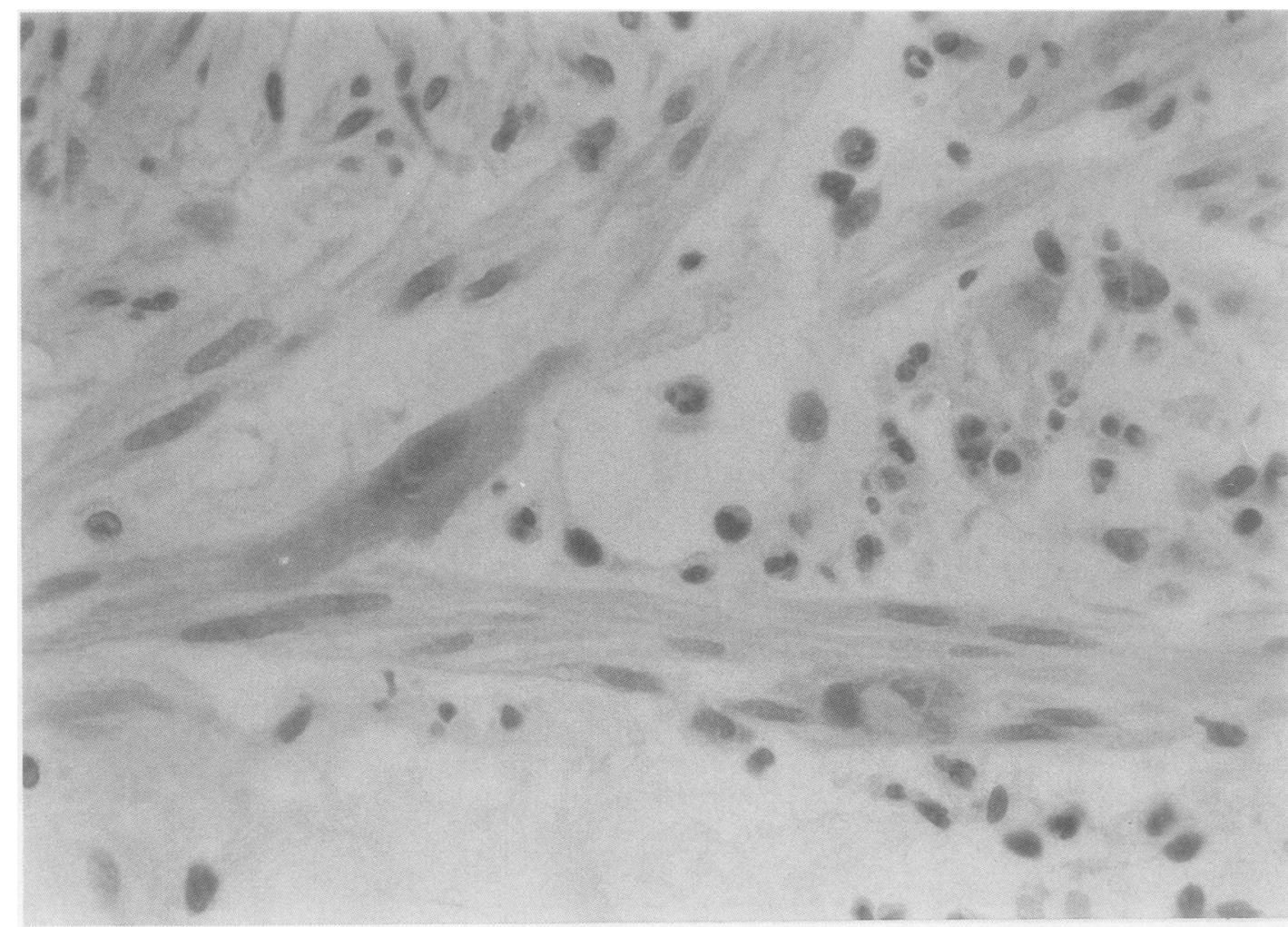

Fig 5 Colonic muscularis mucosa cells infected with CMV showing different morphological types.

Fig 6 Infected gastric epithelial cells showing nuclear and fine granular cytoplasmic inclusions. 


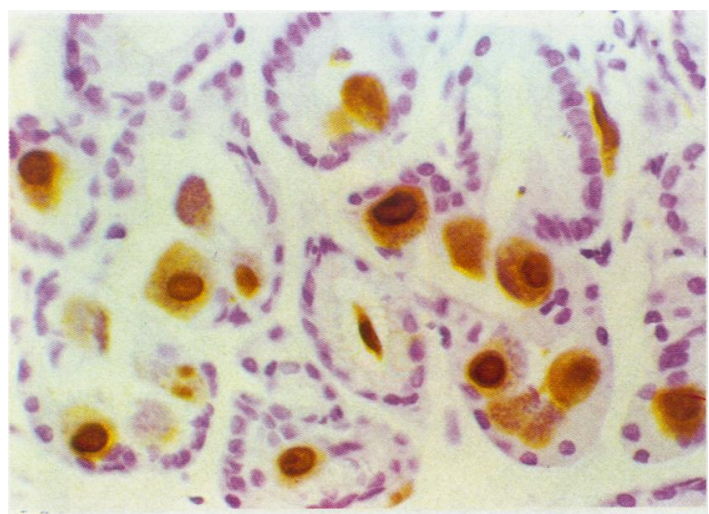

Fig 7 Anti-CMV antibody staining of infected gastric epithelial cells showing strong nuclear and cytoplasmic staining.

In the stomach and small intestine classic inclusion cells were often seen in large numbers in glandular epithelial cells with relatively few in the lamina propria. In this site, however, atypical infected cells were often shown by immunocytochemical techniques. Associated inflammatory changes were usually mild without mucosal ulceration or epithelial cell necrosis.

In the colorectal biopsy specimens infected cells were often few in number and only seen in one case in the colonic epithelial cells in association with an area of superficial ulceration. Endothelial cells, pericytes, and lamina propria cells were the usual sites of infection. Muscle cells were infected in eight cases and often showed atypical morphology. Muscle cells were not infected in specimens from the upper gastrointestinal tract and were only found in one of the perianal biopsy specimens.

The morphological appearances of CMV infected cells were variable. The classic owl's eye (Cowdry type A) inclusions were seen (fig 1), but they were the exception rather than the rule. More common were slightly enlarged elongated cells with tapering cytoplasm and indistinct haematoxyphilic smudged nuclei (figs 2 and 3 ). In some cases these were difficult to distinguish from hypertrophied endothelial cells in areas of inflammation. Intermediate forms were often present showing large rounded nuclei but without the halo around the intranuclear inclusion. These were seen particularly in endothelial cells, pericytes, lamina propria and muscle cells (figs 3, 4, and 5). Some of these and the more typical cells also contained cytoplasmic inclusions (fig 6), a feature which also differentiates them from cells infected with cytomegalovirus from those infected with adenovirus. $^{310}$ These cytoplasmic inclusions may resemble the bradyzoites of Toxoplasma gondii when nuclear

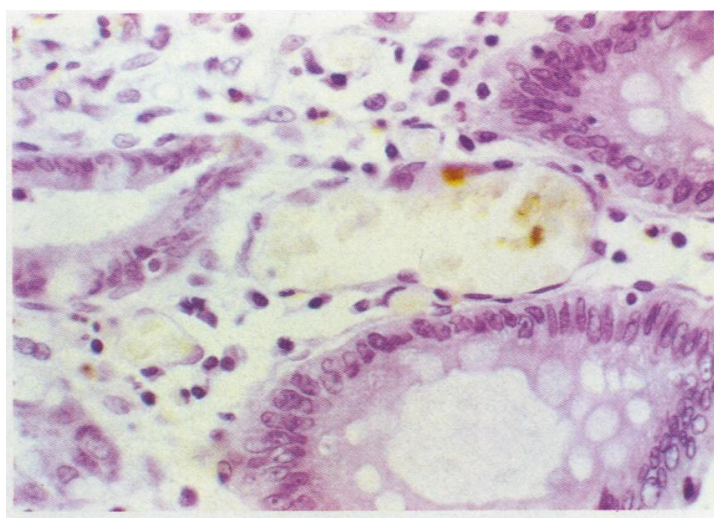

Fig 8 Positive staining of an endothelial cell which does not show typical morphology of an infected cell.

inclusions are not present. The latter, however, are more regular in size and contained within a well demarcated cytoplasmic pseudocyst. ${ }^{3}$

The number of CMV infected cells was associated with the severity of disease and in the more severe cases response to treatment was greater in those with larger numbers of CMV cells.

Immunocytochemical techniques showed positive staining in all the cases tested. Both nuclear and cytoplasmic staining were seen (fig 7), corresponding to early and late and early antigen, respectively, which the antibody recognises. Staining of intracytoplasmic inclusions was often weak or absent. Immunocytochemistry was particularly useful in all sites for identification of parts of infected cells where the nucleus was not present in the section, and in identifying cells which would otherwise not be recognised as infected from morphological detail alone (fig 8).

Electron microscopic examination confirmed the presence of herpes type viral particles in the nucleus and cytoplasm of infected cells. None was found to have particles compatible with adenovirus, as defined by sizing and ultrastructural morphology. Measurement of the particles was in the range 135-142 $\mathrm{nm}$ (encapsulated) and 80-100 nm (unencapsulated) with morphological features of CMV (fig 9). ${ }^{1012}$

\section{Discussion}

Cytomegalovirus is common in the general population, with evidence of infection in $10-30 \%$ of children rising to $60-90 \%$ at 60 years. ${ }^{13}$ In the homosexual population nearly $100 \%$ have evidence of past infection and $15 \%$ have detectable CMV in the urine. ${ }^{14}$

In HIV antibody positive patients the underlying immune deficiency makes serological diagnosis of active CMV infection unreliable. ${ }^{\text {s }}$ Although CMV 


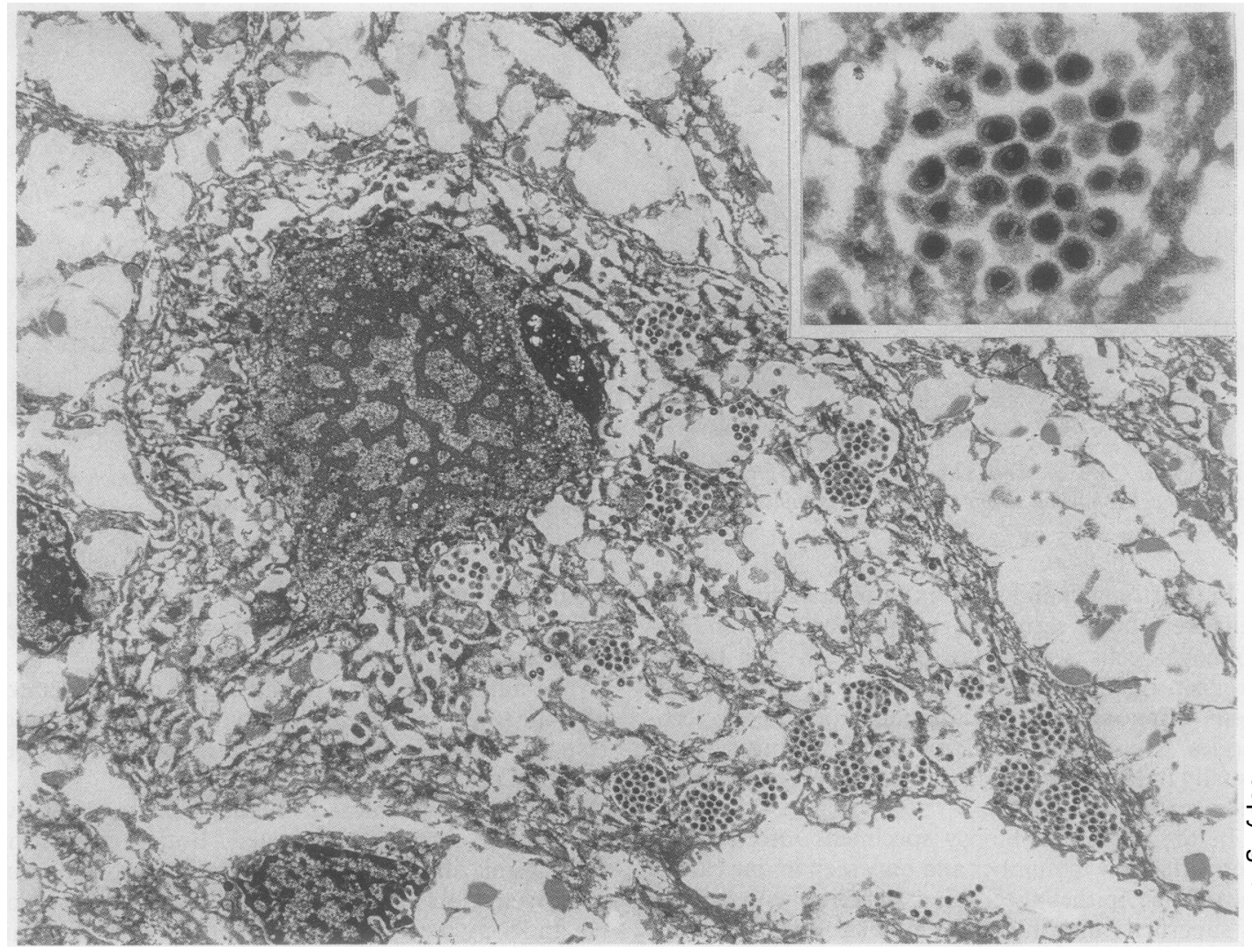

Fig 9 Electron micrograph of infected gastric epithelial cell showing clusters of viral particles in the cytoplasm and less easily seen in the nucleus. Inset shows detail of intracytoplasmic particles.

cultured from the blood or buffy coats indicates active infection, because of its multisystem effects it cannot be taken as direct evidence that CMV causes gastrointestinal symptoms. The diagnosis therefore rests on identification of infected cells or positive culture in tissue specimens from the affected site. Even then its clinical importance may not be clear in the presence of other pathogens.

Necropsy studies have shown that CMV may be one of the most commonly underdiagnosed infections in patients with AIDS during life..$^{316}$ Now that effective treatment against $\mathrm{CMV}$ is available ${ }^{117-20}$ it is even more important that maximal diagnostic sensitivity is achieved in specimens from these patients during investigation. It is also important as one of the principal diagnoses in the case definition of AIDS.' Studies of enteric pathogens in AIDS have repeatedly shown a wide range of potential causes, of which CMV has been implicated in up to $58 \%$ of patients presenting with diarrhoea and other gastrointestinal tract symptoms, ${ }^{121-23}$ but CMV seems to be a rare pathogen in AIDS cases in Africa. ${ }^{24} 25$
Reports of CMV in the gastrointestinal tract have mainly been case reports or small series, ${ }^{2026-35}$ few of which have described the problems of recognition or location of infected cells in detail. ${ }^{36}$ More recently there have been several reports describing occult infection using monoclonal antibodies ${ }^{37}{ }^{38}$ or in situ hybridisation to detect infected cells. ${ }^{38-41}$ These reports show that immunocytochemistry is more sensitive than ordinary staining methods at detecting infected cells and indicates positive cells that would otherwise not have been recognised. Although some series show an even greater sensitivity with in situ hybridisation, other groups do not. The use of the polymerase chain reaction (PCR) is likely to enhance this method of diagnosis. ${ }^{42}$ It is clear, however, that immunocytochemical positivity indicates active viral replication whereas in situ hybridisation and PCR may merely 0 allow latent virus in tissue to be detected and positivity would therefore not indicate active disease.

Our study emphasises the point that immunocytochemical techniques are more sensitive than ordinary staining methods and also draws attention to the 
morphology of cells that previously may not have been regarded as infected with CMV. Semiquantitative analysis indicates that this may be important in determining the likely response to treatment, but this needs full prospective evaluation. We have also described the wide range of cell types that may be infected and that cell susceptibility seems to differ at different sites in the gastrointestinal tract. At all sites endothelial lamina propria cells, including macrophages and pericytes, were often infected. The particularly interesting findings were the rarity of squamous epithelial cell infection and the common finding of infected muscle cells, which was mostly confined to the large bowel. It is perhaps not surprising that muscularis mucosa cells can be infected when it is known that pericytes are often infected and that they are considered to be modified smooth muscle cells. More difficult to explain is the lack of infection of squamous cells when we know that they are frequently infected by other herpes group viruses such as Epstein Barr virus and herpes simplex virus and, indeed, may be a preferential site for the replication of Epstein Barr virus. $^{343}$

The mechanisms by which CMV produces tissue damage are not known. Vasculitis has been reported in some cases ${ }^{27}{ }^{31-33}$ and suggested as the basis for necrosis and ulceration. In our series none of the cases had active vasculitis and only one case had a small thrombus in a vessel at the junction of the lamina propria and muscularis. Therefore, although important in some cases, it does not seem to be the main mechanism. Muscle cell destruction has been suggested as the basis for perforation, ${ }^{29}$ and our findings would support the fact that muscle infection may be important. None of our cases, however, presented with or developed bowel perforation.

Since the observation that activated endothelial cells are more susceptible to infection by $\mathrm{CMV}^{44}$ there has been debate over whether it is a primary infective agent or a secondary invader of already inflamed tissues. ${ }^{273334364546}$ The tissue damage seen in our patients ranged from mild chronic inflammation with oedema to ulceration and necrosis, and none of the cases was histologically normal. The fact that seven of these cases had other infectious agents or Kaposi's sarcoma means that we cannot conclude that CMV was primarily or solely responsible for the symptoms. In 11 cases, however, CMV was the only identifiable pathogen that could be implicated and eight of these responded to treatment for CMV. The three cases with perianal CMV were not treated. This does not exclude the possibility that HIV-1 may have a direct role in producing tissue damage and symptoms, ${ }^{47}$ but evidence from cases of CMV retinitis indicates that CMV can act as a primary pathogen where HIV cannot be detected. ${ }^{48}$

The culture of adenovirus from the stools of three of the patients was one of the main reasons for electron microscopic examination. It has been suggested that adenovirus might be a pathogen in enterocolitis, ${ }^{49}$ but our study shows that the cytomegalic cells found in these cases had the ultrastructural features of CMV, not adenovirus, and this was confirmed by immunocytochemical staining.

The clinical importance of finding CMV infected cells in the absence of morphologically abnormal cells is not clear. In patients with active CMV infection there is a phase of early antigen production with an associated IgM antibody response,,$^{50}$ a phase of late antigen production, and eventually a latent inactive infection with CMV genomic material incorporated in the host cell nucleus. The virus may then be reactivated at a later stage or new infection may occur. It is generally accepted that active viral replication is indicated if early and or late antigen can be shown in the cell. As the antibody used detects both early and late antigen it is concluded that positivity is evidence of active viral infection and that $\mathrm{CMV}$ is the likely cause of associated tissue damage and symptoms.

\section{References}

1 Jacobson MA, Mills J. Serious cytomegalovirus disease in the acquired immunodeficiency syndrome (AIDS). Ann Int Med 1988;108:585-94.

2 Wiley CA, Shrier RD, Denaro FJ, Nelson JA, Lampert PW, Oldstone MRA. Localization of cytomegalovirus protein and genome during fulminant central nervous system infection in an AIDS patient. J Neuropathol Exp Neurol 1986;45:127-39.

3 Klatt EC, Shibata D. Cytomegalovirus infection in the acquired immunodeficiency syndrome. Arch Pathol Lab Med 1988; 112:540-4.

4 Laughon BE, Druckman DA, Vernon A, et al. Prevalence of enteric pathogens in homosexual men with and without acquired immunodeficiency syndrome. Gastroenterology 1988;94:984-93.

5 Knapp AB, Horst DA, Eliopoulos G, et al. Widespread cytomegalovirus gastroenterocolitis in a patient with acquired immunodeficiency syndrome. Gastroenterology 1983;85: $1399-402$.

6 Rosen P, Armstrong D, Rice N. Gastrointestinal cytomegalovirus infection. Arch Intern Med 1973;132:274-6.

7 Nelson JS, Wyatt JP. Salivary gland virus disease. Medicine 1959;38:223-41.

8 Gazzard B. AIDS. Clin Gastroenterol 1987;1:567-87.

9 Centers for Disease Control. Revision of CDC surveillance case definition for acquired immunodeficiency syndrome. $M M W R$ 1987;36(supp 1S);3S-15S.

10 Smith J, Coleman DV. Electron microscopy of cells showing viral cytopathic effects in papanicolaou smears. Acta Cytol 1983;27:605-13.

11 Neilson RH, Orholm M, Pedersen JO, Hovind-Hougen K, Teglbjaerg PS, Thaysen EH. Colorectal spirochaetosis: clinical significance of the infestation. Gastroenterology 1983;85:62-7.

12 Donnellan WL, Chantra-Umporn Sand Kidd JM. The cytomegalic inclusion cell. Archives of Pathology 1966;82: $336-48$.

13 Starr SE. Cytomegalovirus. Paed Clin North Am 1979;26:283-93.

14 Mintz L, Drew WL, Miner RC, Bratt EH. Cytomegalovirus infection in homosexual men: an epidemiological study. Ann Int Med 1983;98:326-9. 
15 Rasmussen L; Kelsall D, Nelson R, et al. Virus specific IgG and IgM antibodies in normal and immunocompromised patients infected with CMV. J Infect Dis 1982;145:191-9.

16 Wilkes MS, Fortin AH, Felix JC, Godwin TA, Thompson WG. Value of necropsy in acquired immunodeficiency syndrome. Lancet 1988;ii:85-8.

17 Collaborative DHPG treatment study group: treatment of serious cytomegalovirus infections with 9-(1-3,-dihydroxy-2propoxymethyl) guanine in patients with AIDS and other immunodeficiencies. $N$ Engl J Med 1986;314:801-5.

18 Chachoua A, Dieterich D, Krasinski K, et al. 9-(1-3,-dihydroxy-2propoxymethyl) guanine (ganciclovir) in the treatment of cytomegalovirus gastrointestinal disease with the acquired immunodeficiency syndrome. Ann Int Med 1987;107:133-7.

19 Ringden O, Wildzek H, Lonnquvist B, Gharton G, Wahren B, Lenerstedt JO. Foscarnet for cytomegalovirus infection. Lancet 1985; : $1503-4$.

20 Weber JN, Thom S, Barrison I, et al. Cytomegalovirus colitis and oesophageal ulceration in the context of AIDS. Gut 1987;28:482-7.

21 Kotler DP, Gaetz HP, Lange M, Klein EB, Holt PR. Enteropathy associated with the acquired immunodeficiency syndrome. Ann Int Med 1984;101:412-28.

22 Dworkin B, Wormser GP, Rosenthal WS. Gastrointestinal manifestations of the acquired immune deficiency syndrome: a review of 22 cases. Am J Gastroenterol 1985;80:774-8.

23 Gillin JS, Shike M, Alcock N, et al. Malabsorption and mucosal abnormalities of the small intestine in the acquired immune deficiency syndrome. Ann Int Med 1985;102:619-22.

24 Colebunders R, Lusakumuni K, Nelson AM, et al. Persistent diarrhoea in Zairian AIDS patients. Gut 1988;29:1687-91.

25 Sewenkambo N, Mugerwa RD, Goodgame R, et al. Enteropathic AIDS in Uganda. An endoscopic, histological and microbiological study. AIDS 1987;1:9-13.

26 St Onge G, Bezahler GH. Giant oesophageal ulcer associated with cytomegalovirus. Gastroenterology 1982;83:127-30.

27 Frank D, Raicht RF. Intestinal perforation associated with cytomegalovirus infection in a patient with acquired immune deficiency syndrome. Am J Gastroenterol 1984;79:201-5.

28 Freedman PG, Weiner BC, Balthazar EJ. Cytomegalovirus esophagogastritis in a patient with acquired immunodeficiency syndrome. Am J Gastroenterol 1985;80:434-7.

29 Fernandes B, Brunton J, Koven I. Ileal perforation due to cytomegaloviral enteritis. Can J Surg 1986;29:453-6.

30 Spiller RC, Lovell D, Silk DBA. Adult acquired cytomegalovirus infection with gastric and duodenal ulceration. Gut 1988;29:1109-11.

31 Meiselman MS, Cello JP, Margaretten W. Cytomegalovirus colitis. Gastroenterology 1985;88:171-5.

32 Freeman HJ, Shnitka TK, Piercy JRA, Weinstein WM. Cytomegalovirus infection of the gastrointestinal tract in a patient with late onset immunodeficiency syndrome. Gastroenterology 1977;73:1397-403.

33 Goodman MD, Porter DD. Cytomegalovirus vasculitis with fatal colonic haemorrhage. Archives of Pathology 1973;96:281-4.

34 Foucar E, Mukai K, Foucar K, Sutherland DER, van Buren CT. Colonic ulceration in lethal cytomegalovirus infection. Am J
Clin Pathol 1981;76:788-801.

35 Rotterdam H, Sommers SC. Alimentary tract biopsy lesions in the acquired immune deficiency syndrome. Pathology 1985;17: 181-92.

36 Henson D. Cytomegalovirus inclusion bodies in the gastrointestinal tract. Archives of Pathology 1972;93:477-82.

37 Myerson D, Hackman RC, Nelson JA, Ward DC, McDougall JK. Widespread presence of histologically occult cytomegalovirus. Hum Pathol 1984;15:430-9.

38 Robey SS, Gage WR, HT(ASCP), Kuhajda FP. Comparison of immunoperoxidase and DNA in situ hybridization techniques in the diagnosis of cytomegalovirus colitis. Am J Clin Pathol 1988;89:666-71.

39 Roberts WH, Hammond S, Sneddon JM, Thesing J, Caldwell JH, Clausen KP. In situ DNA hybridization for cytomegalovirus in colonoscopic biopsies. Arch Pathol Lab Med 1988;112:1106-9.

40 Loning T, Milde K, Foss H-D. In situ hybridization for the detection of cytomegalovirus (CMV) infection. Virchows Arch (Pathol Anat) 1986;409:777-90.

41 Keh WC, Gerber MA. In situ hybridization for cytomegalovirus DNA in AIDS patients. Am J Pathol 1988;131:490-6.

42 Shibata DK, Arnheim N, Martin JW. Detection of human papilloma virus in paraffin-embedded tissue using the polymerase chain reaction. J Exp Med 1988;167:225-30.

43 Allday MJ, Crawford DH. Role of epithelium in EBV persistence and pathogenesis of B-cell tumours. Lancet 1988;i:855-7.

44 Vogel FS. Enhanced susceptibility of proliferating endothelium to salivary gland virus under naturally occurring and experimental conditions. Am J Pathol 1958;34:1069-79.

45 Levine RS, Warner NE, Johnson CF. Cytomegalic inclusion disease in the gastrointestinal tract of adults. Ann Surg 1964;159:37-48.

46 Cooper HS, Raffensperger EC, Jonas L. Cytomegalovirus inclusions in patients with ulcerative colitis and toxic dilatatiog requiring colonic resection. Gastroenterology 1977;72:1253-6

47 Nelson JA, Wiley CA, Reynolds-Kohler C, Reese CE, Margar ten W, Levy JA. Human immunodeficiency virus detected bowel epithelium from patients with gastrointestinal symptoms Lancet 1988;:259-62.

48 Kennedy PG, Newsome DA, Hess J, et al. Cytomegalovirus but not human T lymphotrophic virus type III/lymphadenopathy associated virus detected by in situ hybridisation in retinal lesions in patients with the acquired immune deficiency syndrome. Br Med J 1986;293:162-4.

49 Parkin JM, Tyms S, Roberts A, Burnell R, Jefferies D, Pinching AJP. Cytomegalovirus colitis: can it be caused by adenovirus? (abstract). In: Abstracts of the III International conference on AIDS. Washington, DC: US Department of Health and Human Services, 1987:47.

50 Landini MP, Lazzarotto T, La Placa M. The immune response to human cytomegalovirus-induced early nuclear and early membrane antigens and its possible clinical significance. J Infect 1984;9:257-63.

Requests for reprints to: Dr N D Francis, Department of Histopathology, Westminster Medical School, 17 Horseferry Road, London SW1P 2AR, England. 